\title{
Biomass and species structure of the phytoplankton of an high mountain lake (Lake Paione Superiore, Central Alps, Italy)
}

\author{
Alessandra PUGNETTI* and Roberta BETTINETTI ${ }^{1)}$ \\ C.N.R. Istituto Italiano di Idrobiologia, Largo Tonolli 50, 28922 Verbania Pallanza, Italy \\ ${ }^{1}$ Dipartimento di Biologia, Sezione di Ecologia, Università degli Studi di Milano, 20133 Milano, Italy \\ *e-mail corresponding author: pugnetti@ibm.ve.cnr.it
}

\begin{abstract}
In the framework of the EU MOLAR Project on "Measuring and modelling the dynamic response of remote mountain lake ecosystems to environmental change" a three whole-year study (1996-1998) on the composition and dynamics of phytoplankton community of the high mountain lake, acid sensitive Lago Paione Superiore (LPS) was carried out. The data were analyzed and compared with those gathered during the years 1991-1993. The phytoplankton was made up by nanoplanktonic unicellular algae, the only exception being the colonial Dinobryon sertularia. Just four species, belonging to Chrysophyceae (Chromulina sp., Dinobryon sertularia and Mallomonas alveolata) and to Dinophyceae (Gymnodinium sp.) were important as biomass and density, and they were always present throughout the year. The prevalence of potentially mixotrophic species suggests an adaptive strategy to the low environmental concentrations of inorganic carbon and phosphorus. The seasonal variations of the total biomass were similar to those observed in the previous years. The total number of species has increased; this could be related with the recent increase of the pH and of the alkalinity.
\end{abstract}

Key-words: phytoplankton, high mountain lakes, acidification

\section{INTRODUCTION}

The high mountain lakes are subjected to extreme environmental conditions, as it regards light, temperature and nutrient conditions (Pechlaner 1971). The difficult access often characterizes these environments and therefore basic information about the dynamics and the activity of their biological communities are not abundant, especially concerning the ice-covered period. The biological data are generally scarce for the lakes located in the Italian Alps, but the studies on the communities of the lakes Paione (Italian Central Alps) (Mosello et al. 1993; Pugnetti et al. 1993; Pugnetti \& Bettinetti 1995; Boggero \& Nocentini 1994; Cammarano \& Manca 1997) represent an exception. Most data were gathered in Lake Paione Superiore (LPS) which was included, since the beginning of the 1990s, among the reference sites of two EU projects concerning the remote areas as indicators of regional and global pollution: the AL:PE Program on "Acidification of Mountain Lakes: Paleolimonology and Ecology" (Whatne 1992) and the MOLAR Program on "Measuring and modelling the dynamic response of remote mountain lake ecosystems to environmental change".

In the frame of the AL:PE Program, in addition to macrozoobenthos (Boggero \& Nocentini 1994) and zooplankton (Cammarano \& Manca 1997), a three whole-year study was performed on the phytoplankton composition and dynamics of lakes Paione Superiore and Paione Inferiore (Bettinetti 1994; Pugnetti \& Bettinetti 1995). In the framework of the EU project MOLAR (1996-1998) further information on the phyto- plankton of LPS was gathered with the aim of giving a contribution to the development of an environmental database on remote mountain lake ecosystems and assessing the importance of the phytoplankton biomass in conjunction with the zooplankton and the microbial loop.

In this paper we have analysed the seasonal variations of phytoplankton composition and biomass and compared them with the previous data (1991-93; Pugnetti \& Bettinetti 1995); another article (Callieri et al. 1999, this issue) reports the carbon partitioning among phytoplankton, zooplankton and the components of the microbial loop.

\section{MATERIALS AND METHODS}

Information about the morphometrical, hydrological and chemical characteristics of the lake and its watershed can be found in the paper by The MOLAR Water Chemistry Group (1999, this issue) and are synthetically reported in table 1 .

We sampled the lake 23 times, between July 1996 and October 1998, both under the ice cover and during the ice free period, at two depths, $1 \mathrm{~m}$ from the surface and $1 \mathrm{~m}$ from the bottom, carrying out the field and laboratory work according with the MOLAR methodological protocol (Straškrabová et al. 1999, this issue).

\section{RESULTS AND DISCUSSION}

\subsection{Species composition}

We could identify most of the planktonic algae just at the genus level (Tab. 2); in the whole study period we 
found a total of 18 taxa, so distributed: Chlorophyceae (6), Bacillariophyceae (5), Chrysophyceae (3), Dinophyceae (2), Cryptophyceae (1). All these organisms were unicellular and truly nanoplanktonic, the only exception being the colonial Dinobryon sertularia.

The most important species, as biomass and density, were very few, and all flagellated forms: the Chrysophytes Chromulina sp., Dinobryon sertularia and Mallomonas alveolata and the Dinoflagellate Gymnodinium sp.

Tab. 1. Main geographic, morphometric and chemical chararacteristics of LPS. The chemical parameters are mean volume weighted means for the three years (The MOLAR Water Chemistry Group 1999, this issue).

\begin{tabular}{lcc}
\hline Longitude & $($ East $)$ & $8^{\circ} 11^{\prime} 27^{\prime \prime}$ \\
Latitude & (North) & $46^{\circ} 10^{\prime} 26^{\prime \prime}$ \\
Altitude & $\mathrm{m} \mathrm{a.s.1.}^{2}$ & 2269 \\
Lake area & $\mathrm{km}^{2}$ & 0,014 \\
Watershed area (lake included) & $\mathrm{km}^{2}$ & 0,55 \\
(watershed+lake)/lake & & 39 \\
Maximum depth & $\mathrm{m}$ & 11,7 \\
Mean depth & $\mathrm{m}$ & 5,1 \\
Lake volume & $10^{6} \mathrm{~m}^{3}$ & 69 \\
Dissolved oxygen & $\mathrm{mg} \mathrm{l}^{-1}$ & 9,70 \\
pH & & 5,85 \\
Conductivity & $18^{\circ}{\mathrm{C} \mu \mathrm{Cm}^{-1}}^{-1}$ & 9,32 \\
Alkalinity & $\mu \mathrm{eq} \mathrm{l}^{-1}$ & 0,010 \\
Ammonium & $\mu \mathrm{g} \mathrm{l}^{-1}$ & 36 \\
Nitrate & $\mu \mathrm{g} \mathrm{l}^{-1}$ & 350 \\
Reactive phosphorus & $\mu \mathrm{g} \mathrm{l}^{-1}$ & 1,5 \\
Total phosphorus & $\mu \mathrm{g} \mathrm{l}^{-1}$ & 3,1 \\
Reactive Si & $\mathrm{mg} \mathrm{l}^{-1}$ & 0,49 \\
\hline
\end{tabular}

Tab. 2. List of the phytoplankton taxa identified in LPS during the present research. The most important species are in bold; $*$ indicates the species that were also found in the years 1991-1993 (Pugnetti \& Bettinetti 1995).

\begin{tabular}{|c|c|}
\hline \multicolumn{2}{|c|}{$1996-` 98$} \\
\hline BACILLARIOPHYCEAE & CHRYSOPHYCEAE \\
\hline Achnanthes sp. & Chromulina sp. $*$ \\
\hline Aulacoseira sp. & Dinobryon sertularia * \\
\hline Cyclotella sp. & Mallomonas alveolata $*$ \\
\hline Navicula sp. & unidentified \\
\hline Stephanodiscus sp. & CRYPTOPHYCEAE \\
\hline CHLOROPHYCEAE & Cryptomonas spp \\
\hline Chlamydomonas sp. $1 *$ & DINOPHYCEAE \\
\hline Chlamydomonas sp.2 * & Gymnodinium sp. * \\
\hline cf. Monoraphidium sp. $1 *$ & Peridinium sp. * \\
\hline cf. Monoraphidium sp. $2 *$ & \\
\hline cf. Tetraedron sp. * & \\
\hline Scenedesmus spp & \\
\hline
\end{tabular}

Dinobryon sertularia and also some species of Chromulina and Gymnodinium are known from the literature to be potentially mixotrophic, showing facultative bacterial feeding (Porter 1988; Jones \& Rees 1994; Isaksson 1998). The prevalence of mixotrophic algae in oligotrophic environments is a well known phenomenon, being mixotrophy an optimal strategy when nutrients are low (Isaksson 1998). Therefore it is not surprising to find these forms in LPS; even though we do not have any measurements on the real occurrence of mixotrophy in LPS, the general environmental conditions (low $\mathrm{P}$ and inorganic $\mathrm{C}$ concentrations) could favour it.

Chromulina sp., Mallomonas alveolata and Gymnodinium sp. were the dominant species also in the years 1991-'93 (Pugnetti \& Bettinetti 1995), while Dinobryon sertularia has become much more important in the present study. In comparison with the years 1991-'93 the total number of species has now increased (Tab. 2); this fact cannot be ascribed to methodological differences, being the two periods of study highly comparable as it concerns the number and the volume of samples analysed and the taxonomic accuracy (they were analysed by one and the same operator). It is intriguing to see that the increase of the species number, in particular among diatoms which were never found in the past, has occurred in correspondence with the increase of $\mathrm{pH}$ and alkalinity (The MOLAR Water Chemistry Group 1999, this issue); anyway an hypothesis of a relation between the phytoplankton diversity and $\mathrm{pH}$ in this lake is speculative and it could be verified only with a longtime series of data.

Chromulina sp., Dinobryon sertularia, Mallomonas alveolata and Gymnodinium sp. were present throughout the year and at both depths (surface and bottom). As for the densities (Fig. 1), Chromulina sp. appears to be quite always the dominant species, except in August and September 1997; Dinobryon sertularia generally is most abundant under the ice but it presents a great development even in August 1997, at the near bottom layer; Mallomonas alveolata and Gymnodinium sp. are present throughout the year, the latter with highest abundances in the ice-free period. Among the other species, an unidentified chrysophycean (similar to Uroglena) and Chlamydomonas spp. had some importance in summer and in autumn respectively.

As biomass (Fig. 1), the role of Chromulina sp. is vey much reduced and Dinobryon sertularia and Gymnodinium become dominant, while the relative importance of Mallomonas alveolata is very similar as for density. Besides, in August 1998 also the biomass of Peridinium, negligible in term of density, is remarkable.

\subsection{Total density and biomass}

LPS is ice-covered from November to May-June. The period of "black-ice" (sensu Adams 1976) is quite short and snow falls rather soon after ice formation. The ice cover attains a maximum thickness of about $2.5 \mathrm{~m}$ at the end of the winter. A typical inverse thermal stratification develops under the ice cover. We have just one measurement of light extinction, made in February 1998, when the thickness of the lake cover could be considered close to its maximum: just below the ice the light was reduced to $0.1 \%$ of the incident radiation. Considering what is observed in other high mountain lakes (e.g. Catalan 1992), we can very likely assume that in LPS light falls to $0.1 \%$ of the incident light at the early beginning of the snow accumulation over the ice. 

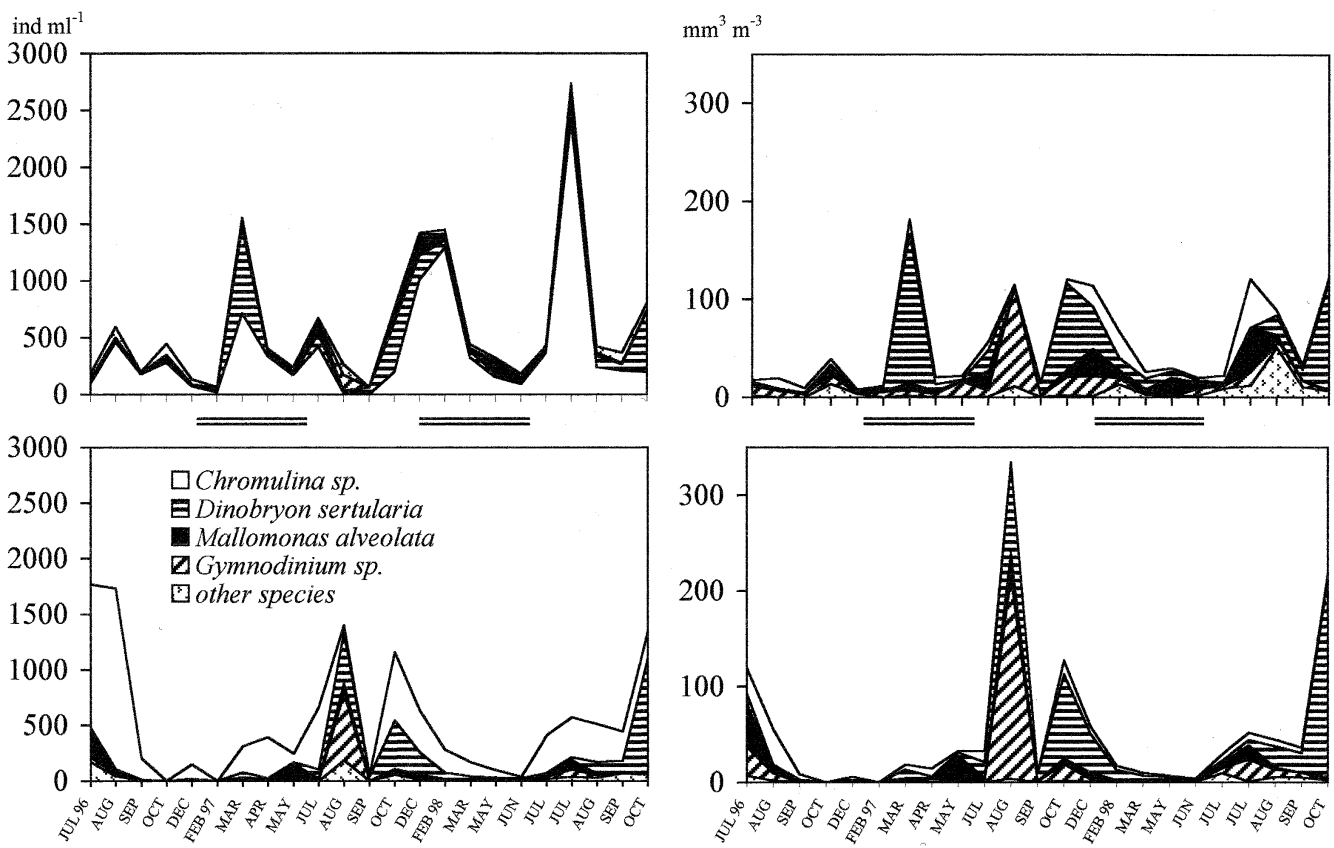

Fig. 1. Time variations of the density (left) and biomass (right) of the most important phytoplankton species in the surface (upper panel) and bottom layer (lower panel) of Lake Paione Superiore, during 1996, 1997 and 1998. Double line represents ice-cover.

Under the ice the phytoplankton showed two different dynamics in the study periods: in winter 1996-1997 the abundances were quite low in the bottom layer, while at surface an isolated peak was observed in the sample gathered in March 1997, representing, it should be stressed, the maximum of the year (Fig. 1). This pattern is not unusual for LPS: it was observed also in 1992 and in 1993 (Pugnetti \& Bettinetti 1995). The composition of phytoplankton in the sample of March indicate an increase of two species, Chromulina sp. and Dinobryon sertularia, that are facultative mixotrophic (Jones \& Rees 1994; Porter 1988; Isaksson 1988). We can only speculate about the occurrence of heterotrophy in this period since we do not have information on the bacterial uptake by those flagellates in LPS under the ice. An indication of the shift of the metabolism towards heterotrophy may come from the low concentrations of the chlorophyll- $a$ (below $0.3 \mu \mathrm{g} \mathrm{l}^{-1}$ throughout the ice-cover period); the concentration did not increase in correspondence of the March abundance peak (Lami, pers. comm.).

In winter 1997-1998 the phytoplankton, both in the surface and in the bottom layer, increased in the first months of ice-cover (from October to December) and then it sharply declined (from February to March); Chromulina sp. and Dinobryon sertularia were the dominant species.

The phytoplankton abundances remained low in both years for the whole ice melting (May-June); we can hypothesize that this pattern, observed also in the past, is determined mainly by the highest flushing rate of this period.
The increase of light, temperature and water column stability in summer determine a new growing phase of the pytoplankton. During this season our data do not indicate a clear vertical differentiation between the surface and the bottom layer of both the species composition and the abundances. Also in the years 1991-1993, when we analysed the whole water column, the vertical distribution of the phytoplankton was found to be almost uniform during the summer (Pugnetti \& Bettinetti 1995).

The late summer decline of phytoplankton occurs in the period of the increase of the density of Daphnia longispina, the main component of the zooplankton in LPS (Cammarano \& Manca 1997; Manca \& Comoli 1999, this issue). There are not experimental estimates of the grazing activity of Daphnia in LPS, but we should emphasize that these variations of phytoplankton and Daphnia were already observed in the years 1991-1993 (Pugnetti \& Bettinetti 1995) and that the increase of the density of Daphnia gives rise to a decrease of carbon of protozoans and bacteria too (Callieri et al. 1999, this issue).

\section{CONCLUDING REMARKS}

The phytoplankton of LPS have been studied for a total of six years (1991-1993 and 1996-1998); as that it is now possible to outline some basic characteristics of the community.

As it is often observed in alpine lakes and, therefore, considered quite typical for these environments (Pechlaner 1971; Rott 1988), the phytoplankton of LPS is 
dominated by nannoplanktonic phytoflagellates. The unicellular forms prevail, just one colonial species ( $\mathrm{Di}$ nobryon sertularia) was found. The total number of species is low and only 4 species, belonging to Chrysophyceae (3) and to Dinophyceae (1) are quantitatively important and are present throughout the year. Chromulina spp, Dinobryon sertularia and Gymnodinium spp are also known to be potentially mixotrophic, suggesting a possible adaptive strategy to the low environmental concentrations of inorganic carbon and phosphorus. The actual occurrence of an heterotrophic metabolism, at least in some periods of the year, should be investigated with specific experiments concerning the grazing activity of these species.

A quite typical pattern of the seasonal variation of the phytoplankton in the years 1991-1993 (Pugnetti \& Bettinetti 1995) was that the maximum abundance of phytoplankton was always observed at the end of the winter, when the ice and snow cover attained its maximum thickness. During the present study this pattern was observed only at the end of the winter 1996-1997, while a decrease of the phytoplankton abundances was observed in winter 1997-1998 after the first 2 months of ice-cover. Estimates of the metabolic activity (autotrophy $v s$ heterotrophy) of the phytoplankton are needed in order to understand the prevalent adaptive strategy during this long ice-cover period.

Another characteristic of the seasonal variations of the phytoplankton in LPS in the years 1991-1993 was the summer decline in correspondence with the increase of Daphnia longispina. These variations were confirmed also for the present research. There is evidence that the appearance of Daphnia represents a key-event also for the whole microbial loop (Callieri et al. 1999, this issue).

LPS is undergoing noticeable changes in the $\mathrm{pH}$ and alkalinity, two variables that have shown a tendency to increase in the last few years (The MOLAR Water Chemistry Group 1999, this volume). We have observed, in the most recent years, an increase of the total number of species of planktonic algae that could be related with these changing environmental conditions. These data will provide a reference set to evaluate longterm changes that could occur in the phytoplankton community in relation with the chemical ones.

\section{ACKNOWLEDGMENTS}

This research was supported by the EC Project MOLAR - Measuring and modelling the dynamic response of remote mountain lake ecosystem to environmental change ( $\mathrm{N}^{\circ}$ ENV4-CT95-0007) of the Environmental and Climate Programme of the European Commission. We would like to thank Dr D. Ruggiu and Dr M. Felip for the revision of the manuscript and their valuable suggestions.

\section{REFERENCES}

Adams, W.P. 1976. Classification of freshwater ice. Musk Ox, 18: 86-99.

Bettinetti, R. 1994. Variazione stagionale e distribuzione verticale del fitoplancton in due laghi alpini (Lago Paione Superiore e Lago Paione Inferiore, Val d'Ossola). Tesi di Laurea, Università degli Studi di Milano: 156 pp.

Boggero, A. \& A.M. Nocentini. 1994. Macrozoobentos di un lago alpino d'alta quota (Lago Paione Superiore, Val Bognanco). Atti del $10^{\circ}$ Congresso AIOL, Alassio 4-6 Novembre 1992: 177-187.

Callieri, C., A. Pugnetti \& M. Manca. 1999. Carbon partitioning in the food web of a high mountain lake: from bacteria to zooplankton. In: Straškrabová, V., C. Callieri \& J Fott (Eds), Pelagic food web in mountain lakes. MOuntain LAkes Research Program. J. Limnol., 58(2): 144-151.

Cammarano, P. \& M. Manca. 1997. Studies on zooplankton in two acidified high mountain lakes in the Alps. Hydrobiologia, 356: 97-109.

Catalan, J. 1992. Evolution of dissolved and particulate matter during the ice-covered period in a deep, high-mountain lake. Can. J. Fish. aquat. Sci., 49: 945-955.

Isaksson, A. 1998. Phagotrophic phytoflagellates in lakes - a literature review. Arch. Hydrobiol. Spec Issues Advanc. Limnol., 51: 63-90.

Jones, R.I \& S. Rees. 1994. Influence of temperarure and light on particle ingestion by the freshwater phytoflagellate $D i$ nobryon. Arch. Hydrobiol., 132(2): 203-211.

Manca, M. \& P. Comoli. 1999. Studies on zooplankton of Lago Paione Superiore. In: Straškrabová, V., C. Callieri \& J Fott (Eds), Pelagic food web in mountain lakes. MOuntain LAkes Research Program. J. Limnol., 58(2): 131-135.

Mosello, R., A. Lami, P. Guilizzoni, M. Manca, A.M. Nocentini, A. Pugnetti, A. Boggero, A. Marchetto, G.A. Tartari, R. Bettinetti, M. Bonardi \& P. Cammarano. 1993. Limnological studies on two acid sensitive lakes in the Central Alps (Lakes Paione Superiore and Paione Inferiore, Italy). Mem. Ist. Ital. Idrobiol., 51: 127-146.

Pechlaner, R. 1971. Factors that control the production rate and biomass of phytoplankton in high-mountain lakes. Mitt. Internat. Verein. Limnol., 19: 123-145.

Porter, K.G. 1988. Phagotrophic phytoflagellates in microbial food webs. Hydrobiologia, 159(1): 89-97.

Pugnetti, A. \& R. Bettinetti. 1995. The phytoplankton of two acid sensitive alpine lakes (lakes Paione, Central Alps, Italy). Mem. Ist. ital. Idrobiol., 53: 39-52.

Pugnetti, A., M. Manca, A.M. Nocentini, A. Boggero, R. Bettinetti, M. Bonardi \& P. Cammarano. 1993. Ecological aspects of two alpine lakes (lakes Paione, Italy). Proc. 5th Conf. Conservation and Management of Lakes, Stresa, May 17-21: 440-443.

Rott, E. 1988. Some aspects of the seasonal distribuiton of flagellates in mountain lakes. Hydrobiologia, 161: 159170 .

Straškrabová, V., C. Callieri, P. Carrillo, L. Cruz-Pizarro, J. Fott, P. Hartman, M. Macek, J.M. Medina-Sánchez, J. Nedoma \& K. Šimek. 1999. Investigations on pelagic food webs in mountain lakes - aims and methods. In: Straškrabová, V., C. Callieri \& J Fott (Eds), Pelagic food web in mountain lakes. MOuntain LAkes Research Program. J. Limnol., 58(2): 77-87.

The MOLAR Water Chemistry Group. 1999. The MOLAR Project: atmospheric deposition and lake water chemistry. In: Straškrabová, V., C. Callieri \& J Fott (Eds), Pelagic food web in mountain lakes. MOuntain LAkes Research Program. J. Limnol., 58(2): 88-106.

Whatne, B.M. 1992. Acidification of mountan lakes: paleolimnology and ecology. The AL:PE project. Documenta Ist. ital. Idrobiol., 32: 7-22. 